\title{
DISCOVERING FACTORS THAT AFFECT IGEN ACADEMIC PERFORMANCE IN THE UNIVERSITY
}

\author{
NURUL NADHILAH FEIZAL ${ }^{1}$, SHAHNAZ ISMAIL ${ }^{1 *}$, WAN ZURIATI WAN \\ ZAKARIA $^{1}$, AND NADIA MOHD NAWI ${ }^{2}$ \\ ${ }^{1}$ Faculty of Business, Economics and Social Development, Universiti Malaysia Terengganu, 21030 \\ Kuala Nerus, Terengganu, Malaysia \\ ${ }^{2}$ English Language Centre, Centre of Fundamental and Continuing Education, Universiti Malaysia \\ Terengganu, 21030 Kuala Nerus, Terengganu, Malaysia
}

*Corresponding author: shahnaz@umt.edu.my

http://doi.org/10.46754/umtjur.2021.01.009

\begin{abstract}
The advancement of technology in digital revolution such as Internet of Things has gained attention in all over the world. This myriad of technology innovations affects all aspects of the human lives today. The generation who has grown up during this era, known as the iGens, mostly relies on the technology in every aspect of their lives, including education. Thus, technology also gives profound impact in educational transformation nowadays to convey innovative education. However, lack of innovation in education becomes a challenge to meet this demand. Therefore, this study was carried out with the aim to discover factors which may affect academic performance of the iGen students in the university. A total of 250 self-administered questionnaires were distributed to the accounting students at UMT with a response rate of $93.6 \%$ (234). Using multiple regression analysis, the findings showed that parental involvement and student's attitude contribute more towards academic performance of iGen students rather than the technology itself. This finding showed that human factor such as support from their parents and individual factor are vital towards their academic performance regardless of from technology savvy generation or not.
\end{abstract}

Keywords: Academic performance, parent involvement, attitude, technology, iGen, Gen Z

\section{Introduction}

Student's academic performance is an indicator for measuring the quality of the students from academic perspective. It is often referred as an extent to which a student, educator or institution achieved educational goals in the short-term and long-term period. Most common measurements for academic performance are examinations, continuous assessments of students' knowledge or capabilities upon completion of any courses or programs. Thus, academic performance provides evidence on the learning outcomes of their on-going learning process across the courses or programs. At the university level, academic performance is measured by students' grade point average (GPA) or cumulative grade point average (CGPA) results. The GPA result will give the greater insight onto the relative level of performance by the individuals and commonly used by researchers in measuring academic performance (Giunchiglia et al., 2018; Lau, 2017).

Meanwhile, iGen (iGeneration) refers to individuals who were born from 1996 to the early 2000s (Gould et al., 2019), who were the 'digital natives' cohort that follows after the Generation Y (Rodriguez et al., 2019). iGens were also known as Gen $Z$ (Generation Z), Gentech, Gen Wii or Net Gen (Othman et al., 2019). This generation was raised up in a digital world (Gould et al., 2019) which is during the advancement of internet usage and social networks where communication and entertainment are at their finger tip, such as Cell Phones, iPod, Facebook, YouTube and IM(instant 
message). Therefore, technology has become an ongoing challenge in all aspects of life of iGen students.

\section{Motivation of Study}

Each generation would act accordingly to the surroundings they are in, which makes each of them is unique. For iGen, it was found to be more of a visual learner despite of kinesthetic (Othman et al., 2019), which might influence their academic performance from previous generations. The iGen students were surrounded by the digital technology, which make them more skillful and comfortable towards technology, compared to the previous generations (Gould et al., 2019). Thus, the influence of such technologies have become the ongoing challenge in all aspects in the life of iGen including academics. As they also depend on the technology as one of the mediums in learning, this kind of situation might become as barrier in both teaching and learning activities. The iGen students were found to be visual learners (Othman et al., 2019), therefore having such generation of students in campus requires the university to change their system of teaching from traditional to technology based. For instance, a massive open online course (MOOC) was recently introduced in the university, which enables students to participate in online classes with the easy access to teaching materials without limit, which suits the need of the iGen cohort. However, their high dependency towards technology in gathering information may lead to less interaction with peers and lecturers.

Therefore, it is important to investigate whether their reliance on technology has affected the iGen academic performance or not. If not, what are the factors may affect their academic performance? As a result, many studies have investigated academic performance with factors, such as parental involvements (Harper et al., 2012; McNeal,
2014), student's attitude (McNeal, 2014), teaching effectiveness (Lee et al., 2009) and technology (Lau, 2017). Based on the above mention scenarios, this study seeks to investigate factors that affect academic performance of iGen cohort in the university, focusing on the accounting students in UMT.

\section{Literature Review, Hypothesis Development and Conceptual Framework}

\section{Academic Performance}

Graduate students depend on their academic performance in higher education (Minesota, 2007). According to Masrom and Usat (2015), academic performance is referred as students' reporting of past semester cumulative grade point average (CGPA) or grade point average (GPA) of each semester. In general, the indicator for academic performance is students' GPA and CGPA (Mushtaq \& Nawaz, 2012; Sansgiry \& Ukwe, 2015; Lau, 2017) or tests and previous year's results (Zhang, 2015; Hijazi \& Naqvi, 2006). A good result will show a better performance because they are more interested and willing to gain more knowledge on the subjects provided. In general, greater results show that the students are able to manage their life as a university student which reflected on their academic performance. However, different factors may contribute differently towards their academic performance which are important to be investigated.

\section{Parental Involvement}

Parental involvement can be considered as guidance for their children whether in academic or daily life. According to McNeal (2014), parental involvement comprises of parent-child, parent-teacher and parentparent relations which the actions from the relationship help a child to meet or exceed the norms or expectation of the student's 
role. The most common way for educators to conceptualise and measure the relationship is through parent-child involvement either through parent-child discussion or parental monitoring (Mc Neal, 2014). As for higher education, parental involvement includes assignation in the process of choosing the college, college fees, offer to support students and arrange the linked with the campus personal (Daniel et al., 2001). The parent engagement and encouragement will give positive outcomes on academic achievement, healthier interaction between parent-child and decrease the level of stress as mentioned by Barnett et al. (2004). Fan and Chen (2001) describe the parental responsibility on their children by giving an example such as parenting aspirations for their child's achievement, communication with their child about school, engagement in school-related activities and personnel as well as education-related rules imposed in the home. As pertaining to this matter, children will likely share their education experiences or other problems with their family. Solutions or opinions from family members can motivate the children and help to reduce the stress level. In addition, Harper et al. (2012) had stated that three domains of positive influence in parental support and involvement which includes parents and academic outcomes, parents and social outcomes, parents, and sociopolitical awareness, which show the concern of parents on their child's activities. Mixed results had been identified in previous studies on the relationship between parental involvement and academic performance. Parent involvement was reported to improve academic achievement (McNeal, 2014; Wilder, 2014) while others indicate that it relates with low achievement (Domina, 2005). Based on this, the hypothesis of this study is:

$\mathrm{H}_{1}$. Parental involvement is significant and positively related to academic performance of iGen students.

\section{Attitude}

Attitude plays a central role in student learning process (Mensah et al., 2013). There are three components of attitude, namely, cognitive, behavioural and affective. However, the formation of attitude is experiential as it was formed through experiences (Mensah, et al., 2013). Student's attitude is reflected through their personality, self-motivation, self-discipline, and efforts towards education which is closely related to academic performance (Mc Neal, 2014). Besides that, attitude towards absenteeism is important as Stanca (2006) and Fajar et al. (2019) reported that it affects student academic performance. For instance, attention in class is crucial. Kaviyarasi and Balasubramanian (2018) found that attention is one of the important attitude values that positively affect academic performance as it increases students' interest. However, research on students' attitude and academic performance is inconclusive. Some demonstrated significant positive relationship between student's attitude and academic performance (Mensah et al., 2013) while others demonstrate that gender and student's effort to pass a subject lead towards better academic performance (Marti-Ballester, 2019). Based on different cultural dimension with previous studies, therefore the hypothesis of this study is:

$\mathrm{H}_{2}$ : Attitude is significant and positively related to academic performance of iGen students.

\section{Teaching Effectiveness}

Effective teaching is normally based on educators' input regarding their qualification or instruction delivery and output, such as student's achievement (Tyler, 2011). Fostering a warm and emotional supportive lecture room environment by educatorscould increase students' motivation, engagement in the subject, which leads to comfort in 
expressing themselves and willing to take academic risks (Sandilos et al., 2019). The positive vibes incur positive and respectful interactions (Reyes et al., 2012), enhance students' self-regulation skills and support their academic achievement (Dudek et al., 2018). Research shows that effective educators, perceived by students are those who have good delivery method where they are able to explain important concepts in an easy manner, knowledgeable and available for consultation after class session (Ismail et al., 2017). Today, with the emergence of technology, education can be done through various social media platform. Therefore, $\mathrm{Su}$ and Wood (2012) reported that the major characteristics of effective teaching are good communicator, good in using educational technologies, have a sense of humour and able to interact with students. Besides, effective educator also must be a caring and loving person that showed enthusiasm towards their students (Colker, 2008). Based on previous findings, the hypothesis of this study is:

$\mathrm{H}_{3}$ : Teaching effectiveness is significant and positively related to academic performance of iGen students.

\section{Technology}

Technology is one of the main concerns on students' academic performance. Currently, the higher education is moving towards the Industry Resolution 4.0 (IR 4.0) where teaching and learning has been fully utilised on online-based learning. Currently, the popular medium of online learning is by using social networking platform includes Twitter, Friendster, MySpace, Facebook, Orkut and many others (Helou \& Rahim, 2014). For iGen students who are addicted to social media, it is believed that the use of social media or social networking sites as a teaching platform may help them to improve their capabilities on academic performance. As Junco et al. (2011) reported that the used of Twitter have contribute a positive impact on students' grades whether for their academic and the non-academic curricular discussion. This is because there was an engagement between the students and the faculty via Twitter rather than the traditional way in sharing the additional information outside the classroom. For instance, the application of e-Learning, which is a teaching and learning platform used in the universities nowadays, to incorporate technology into teaching. Therefore, technology is a medium that can be utilized between students and their instructor to stay always connected. For instance, if a lecturer is unable to attend the class, he/she might do an online lecture, video conference or Padlet which reduce the time consuming in order to finish the syllabus. Cox and McLeod (2014) found that the social media channel foster the communication among teachers, students, parents, community members as well as helping on creating the online professional learning communities. Therefore, the hypothesis of this study is:

$\mathrm{H}_{4}$ : Technology is significant and positively related to academic performance of iGen students.

\section{Methodology}

This quantitative research aimed to examine the factors that affect iGen students' academic performance in the university. Four factors were identified through previous research namely, parental involvement, student's attitude, teaching effectiveness and technology. Questionnaire was used as a main instrument to gather data and was adapted from the study by Mushtaq and Khan (2012) and Ali et al. (2013). The questionnaires were divided into two sections where section A consists of the dependent and independent variables, while section $B$ is the demographic information of the respondents. In section A, Likert Scale of five scales were used namely, $1=$ Strongly Disagree (SD), $2=$ Disagree (D), 3= Neutral (N), 4= Agree 
(A) and 5= Strongly Agree (SA). The questions consist of the dependent variable, which is academic performance with 4 items questions, followed by four factors, which are the independent variables with questions between 4 to 9 for each variable.

The survey was carried out using purposive sampling technique, through selfadministered questionnaires, distributed to the students of the degree in accounting at Universiti Malaysia Terengganu (UMT).
Two hundred and fifty questionnaires were distributed during week 7 of the academic year 2018/2019. Only 234 (93.6\%)

questionnaires were returned, complete and valid to be used for further analysis. The reliability of the distributed questionnaires indicate as good and strong consistency as the Cronbach Alpha shows the value is between 0.683 to 0.905 , as tabulated in Table 1 (Moss et al., 1998; Sekaran and Bougie, 2011; Gliem \& Gliem, 2003).

Table 1: Cronbach alpha result

\begin{tabular}{lcc}
\hline Variables & Cronbach Alpha & Item \\
\hline Academic Performance & 0.683 & 4 \\
Parental Involvement & 0.862 & 4 \\
Students' Attitude & 0.695 & 9 \\
Teaching Effectiveness & 0.905 & 6 \\
Technology & 0.871 & 5 \\
\hline
\end{tabular}

\section{Results and Discussion}

\section{Descriptive Analysis}

Majority of the respondents in this study are female with 73.5 percent $(n=172)$ and male only comprises of 26.5 percent $(n=62)$. This result is common as there are less male in the accounting degree program in UMT. Most of the respondents are Malays with 76.1 percent $(n=128)$, followed by Chinese 17.1 percent $(n=40)$, Indian 4.7 percent $(n=11)$ and other 2.1 percent $(n=5)$. The respondents' age range is between 18 to 24 years old, whereas 50 percent of them are between 18-20 years old, and known as iGen cohort because they who were born in the year 1995 to 2001. Most of the respondents were year 1 students (45.7 percent, $n=107$ ) and 82.5 percent $(n=193)$ of the respondents were found to have basic knowledge in accounting before pursuing for the degree program in UMT. 81.6 percent $(n=191)$ of the respondents are being funded through loans and scholarship and only 18.4 percent $(n=43)$ were self-funded. The respondents were excellent students before entering UMT where 58.5 percent $(n=137)$ obtained 3.5 to 4.0 of CGPA but only 45.6 percent $(n=109)$ maintained this CGPA range in the current year. The details of descriptive results are as tabulated in Table 2.

Table 2: Frequency analysis

\begin{tabular}{llcc}
\hline \multicolumn{1}{c}{ Items } & & Frequency & Percent \\
\hline Gender & Female & 172 & 73.5 \\
& Male & 62 & 26.5 \\
\hline Race & Malay & 128 & 76.1 \\
& Chinese & 40 & 17.1 \\
& Indian & 11 & 4.7 \\
& Others & 5 & 2.1 \\
\hline
\end{tabular}




\begin{tabular}{llcc}
\hline Age & 18-20 years & 117 & 50.0 \\
& $21-23$ years & 112 & 47.9 \\
& 24 years and above & 5 & 2.1 \\
\hline Year of study & Year 1 & 107 & 45.7 \\
& Year 2 & 37 & 15.8 \\
& Year 3 & 34 & 14.5 \\
& Year 4 & 56 & 23.9 \\
\hline Accounting & Yes & 193 & 82.5 \\
background & No & 41 & 17.5 \\
\hline Sponsorship & Parents & 43 & 18.4 \\
& PTPTN & 145 & 62.0 \\
& JPA & 21 & 9.0 \\
& State government & 11 & 4.7 \\
& Others & 14 & 6.0 \\
\hline CGPA during & $2.01-2.50$ & 2 & 0.9 \\
admission & $2.51-3.00$ & 11 & 4.7 \\
& $3.01-3.50$ & 43 & 18.4 \\
& $3.51-4.00$ & 137 & 58.5 \\
\hline Current GPA & $2.01-2.50$ & 2 & 0.9 \\
& $2.51-3.00$ & 16 & 6.8 \\
& $3.01-3.50$ & 77 & 32.9 \\
& $3.51-4.00$ & 32 & 13.7 \\
\hline Current CGPA & $2.01-2.50$ & 3 & 1.3 \\
& $2.51-3.00$ & 15 & 6.4 \\
& $3.01-3.50$ & 67 & 28.6 \\
& $3.51-4.00$ & & 17.9 \\
\hline
\end{tabular}

\section{Correlation Analysis}

The results from the correlation analysis, which is tabulated in Table 3, shows that all variables are correlated at 1 percent level with correlation value between 0.218 and 0.477 . This shows that the variables were not highly correlated and free from multicollinearity problem (Sekaran, 2000).

Table 3: Correlation analysis

\begin{tabular}{lccccc}
\hline & $\begin{array}{c}\text { Academic } \\
\text { Performance }\end{array}$ & $\begin{array}{l}\text { Parental } \\
\text { Involvement }\end{array}$ & Attitude & Effectiveness & Technology \\
\hline $\begin{array}{l}\text { Academic } \\
\text { Performance }\end{array}$ & 1 & & & & \\
\hline $\begin{array}{l}\text { Parental } \\
\text { Involvement }\end{array}$ & $0.477^{* *}$ & 1 & & & \\
\hline $\begin{array}{l}\text { Student } \\
\text { Attitude }\end{array}$ & $0.416^{* *}$ & $0.286^{* *}$ & 1 & & \\
\hline $\begin{array}{l}\text { Teaching } \\
\text { Effectiveness }\end{array}$ & $0.345^{* *}$ & $0.274^{* *}$ & $0.319^{* *}$ & 1 & \\
\hline Technology & $0.320^{* *}$ & $0.218^{* *}$ & $0.220^{* *}$ & $0.469^{* *}$ & 1 \\
\hline
\end{tabular}

Note: $* *$ : Present significant at $1 \%$ 
Further confirmation on inflation factor (VIF) is less than 1.5. These multicollinearity problem is as shown values further confirmed that there was in Table 4 where the tolerance value no multicollinearity problem among the (TOL) is less than 0.801 and the variance variables.

Table 4: Multicollinearity test results

\begin{tabular}{lll}
\hline & TOL & VIF \\
\hline Parental Involvement & 0.801 & 1.248 \\
Student Attitude & 0.782 & 1.278 \\
Student Learning Pattern & 0.672 & 1.488 \\
Teaching Effectiveness & 0.706 & 1.416 \\
Technology & 0.672 & 1.487 \\
\hline
\end{tabular}

\section{Regression Analysis}

The variables used in the model were analysed using standard method of multiple regression analysis and the detail results are shown in Table 5. The model which comprises of academic performance as the dependent variable and four independent variables (parental involvement, student attitude, teaching effectiveness, technology) shown to be fit at 1 percent level with F-stat value of 30.95 and adjusted R-square of 34 percent. The result is similar with the value reported by Ali et al. (2013).

Table 5: Multiple regression analysis result

\begin{tabular}{lll}
\hline Variables & Beta coefficient & t-value \\
\hline Parental Involvement & 0.346 & $6.076^{* *}$ \\
Student Attitude & 0.253 & $4.386^{* *}$ \\
Teaching Effectiveness & 0.104 & 1.656 \\
Technology & 0.140 & $2.300^{*}$ \\
F-stat & $30.953^{* *}$ & \\
R-square & 0.351 & \\
Adjusted R-square & 0.340 & \\
\hline
\end{tabular}

Note: $* * / *$ : Present significant at $1 \% / 5 \%$

The regression results in Table 5 were shown to be positively correlated. shows that most significant element This reveals that parent's aspiration and is parental involvement with the beta expectation for their child's educational value of 0.346 ( $\mathrm{t}=6.076$, sig at 1 percent) achievement showed strong relationship followed by student attitude with beta value of 0.253 ( $\mathrm{t}=4.386$, sig at 1 percent). Both elements (parental involvement and student attitude) were positively related to academic performance of iGen students. Therefore, both hypotheses $\mathrm{H}_{1}$ and $\mathrm{H}_{2}$ were supported. The results supported the findings by Wilder (2014) where parental involvement and academic performance with academic achievement (Fan \& Chen, 2001). Furthermore, student's attitude and academic performance also proven to be related, in line with the findings reported by Mensah, Okyere and Kuranchie (2013).

Technology also shown to be significant and positively related to academic performance with beta value of $0.14(\mathrm{t}=2.30$, sig at 5 percent $)$. In this case, 
hypothesis $\mathrm{H}_{4}$ is supported. This study is consistent with Junco et al. (2011) and GreGory et al. (2014) who found that the use of Twitter and Facebook can enhance university students' engagement and performance when these technologies were used for learning purposes. This shows that technology through the use of social media develop students' interest in academic subjects (Cox \& McLeod, 2014) which then lead to increase the academic performance. This study however unable to find significant relationship between teaching effectiveness and academic performance of iGen students in the university. Thus, $\mathrm{H}_{3}$ is not supported. The cause was unclear and requires further research.

\section{Conclusion}

This study seeks to find the answer for the question on "what are the factors that affect academic performance of iGen students in the university?". The findings of the study revealed that even though iGen students are technology savvy cohort, factors such as parental involvement and students' attitude are the most significant factor that drives the performance of this generation cohort. No doubt, technology shown to be the third significant factor which affect academic performance of these students, after students' attitude. The findings suggested that even though iGen students were devoted or addicted to technology application and they were so called techno-savvy cohort, as a child, the first in line is their parents. They still need their parents' involvement in their life, in this case involvement in their tertiary education. This shows that parents in the digital era still play a significant role in the life of their children and still have strong influence over them. This suggests that human factor and parent-child bonding is vital in human life, no matter which generation there are. So, parent should always encourage, support, motivate, pays attention to their child's needs even though their child is in the tertiary education. Apart from that, attitude of an individual remains important as a push-factor in one life. This is proven from the result of this study which shows that good attitude towards learning leads to higher academic performance. Therefore, lecturers today need to be aware that iGen students still need attention from them. Besides that, lecturers need to be able to challenge themselves in teaching iGen students by modernizing their knowledge and skills that align with current teaching technology in order to be able to deliver the knowledge effectively as well as to attract the attention of the digital savvy students in their class. Thus, lecturers need to be creative in delivering their lectures and need to consider using technology teaching tools such as Kahoot, Padlet, Facebook or Youtube (to name a few) to relate to their students. As for the policy makers in education, such as the Ministry of Higher Education, a reform in the tertiary education should be made to cater the needs of the new millennium cohort group of students who are currently in the universities and colleges. The administration of the universities and colleges should consider integrating advance teaching technology into the syllabus to meet the needs of the future employers who are moving towards the Industrial Revolution 4.0 (IR4.0).

This study is not free from limitations. Firstly, this study focused solely on accounting students in one university alone and secondly, only 34 percent of the variables used in the model were able to explain on academic performance of iGen students. Therefore, another 66 percent could be explained by variables that were not included in this study. There may be other variables besides the ones discussed in this study that may provide significant impact towards academic performance.

Due to these limitations, future research should extend the samples to other public and private universities. A comparison study 
can also be conducted between accounting and non-accounting students. In addition, a detail study on teaching effectiveness among iGen students should be conducted due to the insignificant results obtained from the current study. Further analysis on the impact of technology on academic performance, in example, the use of social media in teaching should be conducted in the future. Such findings could further explain the insignificant result on teaching effectiveness obtained in this study.

\section{Acknowledgements}

The authors acknowledge the helpful comments of anonymous reviewers and participants of the Undergraduate Seminar of School of Maritime Business and Management and the Undergraduate Research Day UMT 2018. The authors would also like to thank the editors of the UMT Journal of Undergraduate Research for their helpful assistance throughout the preparation of this manuscript.

\section{References}

Ali, S., Haider, Z., Munir, F., Khan, H. \& Ahmed, A. (2013). Factors Contributing To The Students Academic Performance: A Case Study Of The Islamia University SubCampus. American Journal of Educational Research, 1(8),283-289.

Barnett, M. (2004). Qualitative analysis of family support and interaction among black college students at an ivy league university. Journal of Negro Education, 73(1), 53-68.

Colker, L.J., (2008). Twelve characteristics of effective early childhood teachers. J. Natl. Accoc. Educ. Young Children, 63:68-73 in the Aregbeyen, O. (2010). Students' perceptions of effective teaching and effective lecturer characteristics at the University of
Ibadan, Nigeria. Pakistan Journal of Social Sciences, 7(2), 62-69.

Cox, D., \& McLeod, S. (2014). Social media strategies for school principals. NASSP Bulletin, 98(1), 5e25 in the Lau, W. W. (2017). Effects of social media usage and social media multitasking on the academic performance of university students. Computers in human behavior, 68, 286-291.

Daniel, B.V., Evans, S.G., \& Scott, B.

R. (2001). Understanding family involvement in the college experience today. New Directions for Student Services, 94, 3-13 in the Wolf, D. S. S., Sax, L., \& Harper, C. E. (2009). Parental engagement and contact in the academic lives of college students. Naspa Journal, 46(2), 325-358.

Dudek, C. M., Reddy, L. A., \& Lekwa, A. (2018). Measuring teacher practices to inform student achievement in high poverty schools: A predictive validity study. Contemporary School Psychology, 1-14.

Domina, T. (2005). Leveling the home advantage: assessing the effectiveness of parent involvement in elementary school. Sociology of Education. 78, 233-249.

Fajar, S., Hussain, M., Sarwar, H., Afzal, M. and Gilani, S.A. (2019). Factors affecting academic performance of undergraduate nursing students. International Journal of Social Science and Management. 6(1), 7-16.

Fan, X., \& Chen, M. (2001). Partental involvement and students se $^{\text {academic }}$ achievement: A meta-analysis. Educational Psychology Review, 13(1), 1-22 in the Wolf, D. S. S.,

Sax, L., \& Harper, C. E. (2009). Parental engagement and contact in the academic lives of college students. Naspa Journal, 46(2), 325-358. 
Gliem, J. A. \& Gliem, R. R. (2003). Calculating, Interpreting, and Reporting Cronbach"s Alpha Reliability Coefficient for Likert-Type Scales. 2003 Midwest Research to Practice Conference in Adult, Continuing, and Community Education.

Giunchiglia, F., Zeni, M., Gobbi, E., Bignotti, E. and Bison, I. (2018). Mobile social media usage and academi performance. Computers in Human Behavior, 82, 177-185.

Gould, D., Nalepa, J. \& Mignano, M. (2020). Coaching generation $\mathrm{z}$ athletes. Journal of Applied Sport Psychology, 32(1), 104-120.

GreGory, P., GreGory, K. \& Eddy, E. (2014). The institutional network: using facebook to enhance undergraduate mathematics instruction. Journal of Computers in Mathematics and Science Teaching, 33(1), 5-26.

Harper, C. E., Sax, L. J., \& Wolf, D. S. S. (2012). The role of parents in college students' sociopolitical awareness, academic, and social development. Journal of Student Affairs Research and Practice, 49(2), 137-156. 35.

Hijazi, S. T., \& Naqvi, R. S. M. M. (2006). Factors affecting students' performance. Bangladesh e-journal of Sociology, 3(1), 1-10.

Ismail, S., Jamaludin, N., Wan Zakaria, W.Z. \& Mohd Nawi, N. (2017). A study on the accounting students' perceptions towards teaching quality at university. International Journal of Accounting, Finance and Business, 2(5), 85-89.

Junco, R., Heiberger, G., \& Loken, E. (2011). The effect of Twitter on college student engagement and grades. Journal of Computer Assisted Learning, 27(2), 119-132 in the Lau, W. W. (2017). Effects of social media usage and social media multitasking on the academic performance of university students. Computers in Human Behavior, 68, 286-291.

Kaviyarasi, R. and Balasubramanian, T. (2018). Exploring the potential factors that affects students' academic performance. I.J. Education and Management Engineering, 6, 15-23.

Lau, W. W. F. (2017). Effects of social media usage and social media multitasking on the academic performance of university students. Computers in Human Behavior, 68, 286- 291.

Lee, P., Sattayawaksakul, D., Waleesila, S., \& Sriharat, P. (2009). Asian students' perceptions of a good college/ university teacher. Catalyst, 4(1), 3-12.

Marti-Ballester, C.P. (2019). Factors that influence academic performance: analyzing gender differences in accounting students. Revista Education, 43(2), 1-16.

Masrom, M., \& Usat, S. (2015). Use of Online Social Networking and Academic Performance of Students. IGI Global. Retrieved 25 July 2019 from https://people.utm.my.

McNeal, R.B. Jr. (2014). Parent involvement, academic achievement and the role of student attitudes and behavior as mediators. Universal Journal of Educational Research, 2(8), 564-576.

Mensah, J.K, Okyere, M. and Kuranchie, A. (2013). Student attitude towards mathematics and performance: does the teacher attitude matter? Journal of Education and Practice. 4(3), 1-8.

Mushtaq, I. and Khan, S.N. (2012). Factors affecting students' academic performance. Global Journal of Management and Business Research, 12(9), 17-22.

Moss, S., Prosser, H., Costello, H., Moss, S., Prosser, H., and Costello, H. (1998) 
Reliability and validity of the PASADD. Journal of Intellectual Disability Research, 42, 173-183.

Othman, M.N.A., Rashid, M.A.A., Ismail, I.R., Norizan, S. \& Saad, S.A.M. (2019). Debunking gen z learning style : Malaysian chapter. International Journal of Advances Research in Technology and Innovation, 1(2), 1-7.

Reyes, M. R., Brackett, M. A., Rivers,

S. E., White, M., \& Salovey, P. (2012). Classroom emotional climate, student engagement, and academic achievement. Journal of Educational Psychology, 104(3), 700-712. https:// doi.org/10.1037/a0027268

Rodriguez, M., Boyer,S., Fleming, D. \& Cohen, S. (2019). Managing the next generation of slaes, gen $\mathrm{z} /$ millennial cusp : an exploration of grit, entrepreneurship, and loyalty. Journal of Business-to- Business Marketing, 26(1), 43-55.

Sandilos, L.E., Sims, W.A., Norwalk, K.E. \& Reddy, L.A. (2019). Converging on quality: Examining multiple measures of teaching effectiveness. Journal of School Psychology, 74(2019), 10-28.

Sekaran, U. and Bougie, R. (2011). Research Methods for Business; A skill business approach. New York: John Willey \& Sons.
Stanca, L. (2006). The Effects of Attendance on Academic Performance: Panel Data Evidence for Introductory Microeconomics, Journal of Economic Education, 37, 251-266.

Su, F., \& Wood, M. (2012). What makes a good university lecturer? Students' perceptions of teaching excellence. Journal of Applied Research in Higher Education, 4(2), 142-155.

Tyler, J. H. (2011). Designing high quality evaluation systems for high school teachers: Challenges and potential solutions in Sadilos, L.E., Sims, W.A., Norwalk, K.E. and Reddy, L.A (2019). Coverging on quality:examining multiple measures of teaching effectiveness. Journal of School Psycholoqy, 74,10-28.

Wilder, S. (2014). Effects of parental involvement on academic achievement: a meta-synthesis. Educational Review, 66(3), 377-397.

Wolf, D. S. S., Sax, L., \& Harper, C. E. (2009). Parental engagement and contact in the academic lives of college students. Naspa Journal, 46(2), 325358.

Zhang, W. (2015). Learning variables, inclass laptop multitasking and academic performance: a path analysis. Computers \& Education, 81, 82-88. 
